\title{
The Classical in Contemporary Art and Visual Culture - an Introduction
}

\author{
Bente Kiilerich
}

\begin{abstract}
This special issue of CLARA titled 'The Classical in Contemporary Art and Visual Culture' focuses on the impact of Greco-Roman antiquity on present day art and culture. Over the last few decades, antique statues have been revived again and again, turning up in new guises in contemporary art from all over the globe. In addition to new works based on specific ancient statues, some artists create art that references the past in a more general way. Other artists question the divide between past and present raising the possibility of 'multi-temporality', a phenomenon that will be explored in connection with recent exhibitions. Another aspect of the interaction of antiquity and the contemporary world is the association between luxury brands and antique monuments, fashion brands taking on the role of patrons, paying large sums for the restoration of Roman landmarks. By studying various types of exchanges between the classical and the contemporary, the papers aim to throw light on why artists and designers continue to draw inspiration from ancient art; in short, why antiquity continues to fascinate.
\end{abstract}

Keywords: contemporary classicism, modern antiquity, appropriation, multitemporality, patronage

In the twenty-first century a great many artists from Europe, America and Asia have offered reinterpretations and reformulations of renowned antique statues. This phenomenon did not occur out of the blue, there being many instances of reformulations also in the late twentieth-century. ${ }^{1}$ Yet, rather than being a fading trend, far from abating, production seems to have escalated in recent years with an increasing number of new works referencing old ones. ${ }^{2}$ Indeed, it might seem as if twenty-first century artworks of antique inspiration are on the verge of outnumbering their extant ancient models. ${ }^{3}$ European artists, especially sculptors, who have presented substantial reworks include, in alphabetical order: Alben, Léo Caillard, Mathew Darbyshire, Omar Hassan, Liane Lang, Bjørn Nørgaard, Francesco Rubino, Yinka Shonibare, Marina

\footnotetext{
${ }^{1}$ Masiero (ed.) 1990; Sanguinetti (ed.) 1995; Di Stefano (ed.) 1998; Kiilerich 2006.

${ }^{2}$ Holmes \& Marta (eds) 2017; Squire (ed.) 2018; Besnard 2018a, 2018b, 2019a, 2019b, 2019c; Kiilerich 2018, 2019, 2021.

${ }^{3}$ Tiphaine Annabelle Besnard's database comprises some 1100 artworks by around 160 international artists from the period 1980-2020.
} 


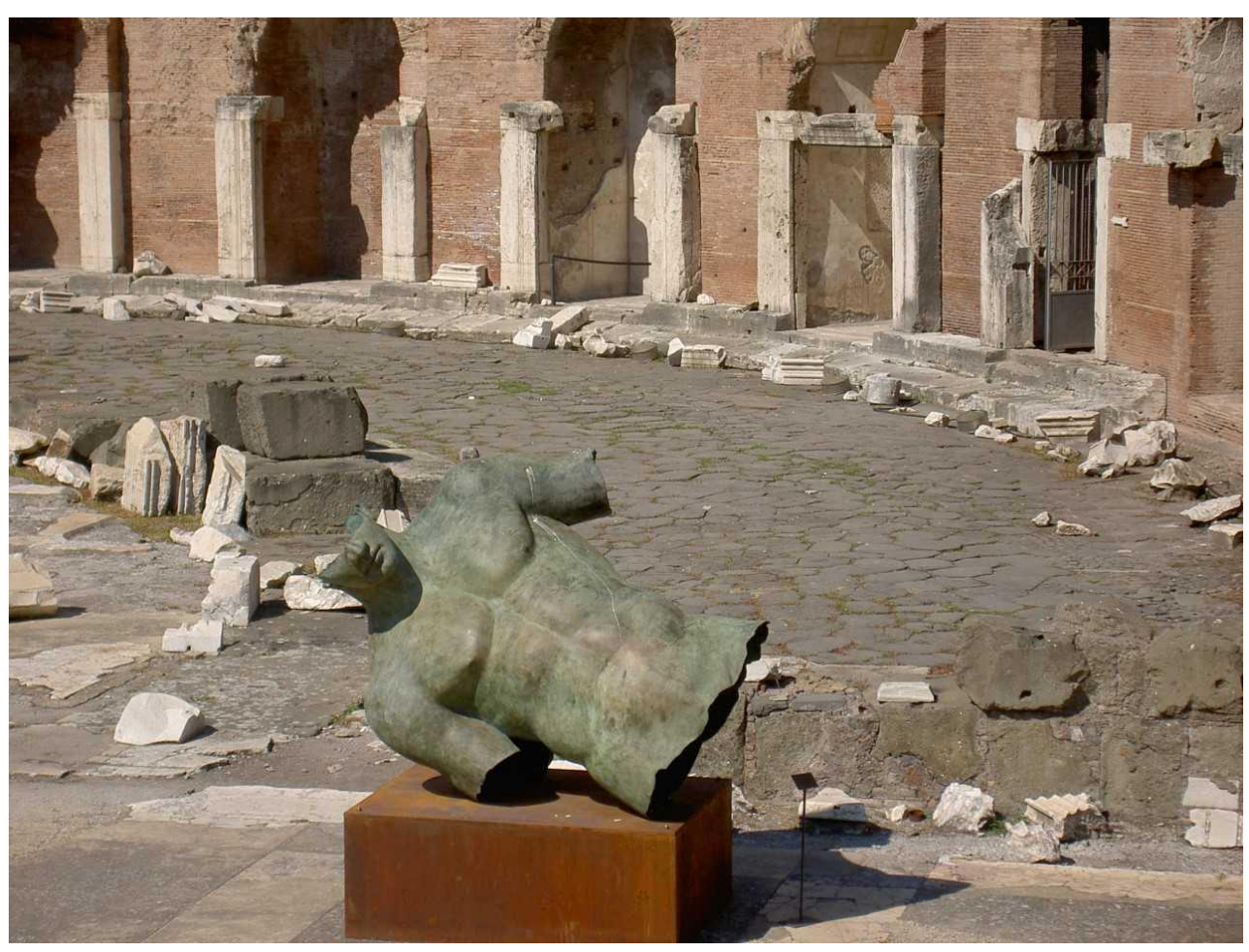

Fig. 1 Igor Mitoraj, Torso di Ikaro, 2000, exhibited in Trajan's Market, Rome, 2004. (C) B. Kiilerich.

Vargas, Francesco Vezzoli and Fabio Viale. In the USA, Daniel Arsham, Barry X Ball, Brett Kern, Jeff Koons, Tony Matelli, Alan Reede and Nick van Woert have similarly engaged with the past, as have the Chinese artists Bai Yiluo, Cao Hui, Li Hongbo, Sui-Jianguo, Tian Xiaolei and Xu Zhen.

In addition to making art based on specific antique statues, sculptors have created works that reference the classical past in various ways: Igor Mitoraj (1944-2014) combined the antique accidental fragment and the modernist tradition of intentional partiality, fashioning enigmatic fragmented figures of Eros, Icarus and Hypnos in both marble and bronze. His 'modern antiquities' include monumental heads, hands, feet and torsos. ${ }^{4}$ The interaction of present and past was strengthened when the sculptures were exhibited at the archaeological sites of Trajan's market in Rome in 2004 (Fig. 1), the Valley of the Temples at Agrigento in 2011, and posthumously at Pompeii in 2016. Interpolated into ancient surroundings, the new works took on the role as remnants of the past. Fragments and fragmentation are characteristic of much contemporary art, as, for instance, in recent installations of Daniel Silver, whose works superficially, at first glance, bring to mind scattered finds from archaeological excavations. ${ }^{5}$

${ }^{4}$ See e.g. Soavi 2003; Costantini 2004; Mitoraj 2004; Kiilerich 2005; Howorus-Czajka 2018.

${ }^{5}$ Kiilerich 2019, fig. 1; see also Trione 2013 for the fragment in Italian art. 
As will be explored in the present issue, it is especially in threedimensional art that the classical has made its mark in the twenty-first century. It seems that sculpture allows for a greater freedom of expression and provides more material possibilities, whereas the place of figurative painting in contemporary culture is slightly problematic, given that figuration in an academic and classical idiom is regarded as conservative and outmoded. Still, there are of course exceptions. In Greece, several painters continue to include references to the classical past. ${ }^{6}$ For instance, Alexandros Isaris has made a series of coloured drawings focusing on the Motya youth from Sicily (2005). ${ }^{7}$ The exhibition Nostos, the homeward journey, brought together a number of works by Iannis Psychopedis, who employs painting, photography and collage in mixed media images that reference Praxiteles' Hermes, the Parthenon and other antique statues and monuments. ${ }^{8}$ The most prolific exponent of the classical in a wide sense is Carlo Maria Mariani (b. 1931), who well into old age still produces immaculate works with allusions to styles and motifs of earlier periods.' His compositions span from the simple to the highly complex, combining classical themes with modern elements and surrealistic traits. ${ }^{10}$ To a certain extent, the immaculate painting style of Californian David Ligare, who regards himself as a postmodern Neo-classical artist, is related to that of Mariani, only the themes differ. Over the last forty years Ligare has made a great number of Mediterranean landscapes and astounding still lifes, some with a head of the Doryphoros depicted against a clear blue sky, as well as classicising figures in quiet contemplation. ${ }^{11}$

Also based in California, Eleanor Antin is well known for her series the Last Days of Pompeii (2001), Roman Allegories (2004) and Helen's Odyssey (2007), which recreate grand, at times decadent, pseudo-antique tableaux depicting people languishing at banquets, in lush (Californian) gardens and in more dramatic situations. ${ }^{12}$ These skilfully composed installations, recorded through large-scale colour photographs, also play on previous classical traditions (e.g. paintings of mythological subjects by Rubens and Poussin). More subdued colours appear in the German artist Liane Lang's series Casts (2006-07) and Spectres (2008). Lang marries the antique and the contemporary in photographs of large plaster casts of antique sculptures interacting with small human forms moulded in various materials. Her unconventional combinations range from humorous grasps of human hands on ancient forms to multiple limbs staged in surrealistic fashion. ${ }^{13}$ On the subject of two-

\footnotetext{
${ }^{6}$ Lambraki Plaka 2000, 2007.

7 Georgiadou-Kountoura 2008.

${ }^{8}$ Mavrotas 2008.

9 In continuation of the pittura colta, ipermanierismo manner of the 1970s and 1980s;

Kaiser 2003.

${ }^{10}$ Lane (ed.) 2011.

11 Shields, Rodes \& Junker 2015.

12 Zummer 2006; Bloom 2009; Filser 2018.

13 Zuschlag 2010, 319-322; https://www.lianelang.com
} 
dimensional representation, another female artist is of interest: Marian Maguire, a New Zealander who references Attic Black-figure vase painting and ancient mythology in her lithographs and etchings. By using excerpts from specific vases and combining them in novel ways, the ancient images and the mock black-figure style create new visualisations that often change the focus from antiquity to the present. ${ }^{14}$

In fashion design, classical mythology and imagery is a recurrent theme. Forty years later, the Medusa Rondanini, chosen as the logo of Gianni Versace in the 1980s, still hypnotises customers from buttons, buckles and perfume flasks. Chanel's 'La modernité de l'Antiquité' campaign from 2017/18 is undeniably 'antique', showcasing models wearing short chitons and golden sandals. ${ }^{15}$ Dolce \& Gabbana, in particular, have dedicated several recent collections to the archaeology of ancient Sicily, presenting exuberant male and female fashions featuring themes ranging from Greek temples and coins, in 2014 , to Greek vases as the main topic in $2019 / 20 .{ }^{16}$ For the latter collection, the floor of the Temple of Concordia at Agrigento served as the catwalk. Gucci was less fortunate as the Greek Archaeological Council declined the use of the Parthenon as a runway for a fashion show in 2017; they deemed it a desecration of the ancient temple. ${ }^{17}$ Instead Gucci filmed their (unclassical) pre-Fall 2019 collection on location at Selinunt. Over the years, many fashion shots have been situated on the steps of temples, in ancient theatres and at other archaeological sites, as if the nostalgic association with the grandeur of the ruined past guarantees the quality of the new designs. Indeed, no matter what they are promoting, advertisers may refer to antiquity when advertising products that are to be associated with notions of harmony, symmetry, beauty and timeless good taste. Thus the Parthenon and the Venus de Milo may advocate any product ranging from food to fashion. ${ }^{18}$

In the wake of twentieth-century postmodernism, antique statues occasionally take their place in contemporary architecture. At Villaroy, $20 \mathrm{~km}$ west of Paris, eighteen Venuses de Milo serve as caryatids carrying a manystoreyed building designed by the Spanish architect Manuel Nunez Yanowsky, 1995-97. ${ }^{19}$ The caryatid motif recurs on a less monumental scale in the Athenian suburb Egaleo, where two apartment buildings display a somewhat eclectic reuse of Greek statuary and architectural sculpture. The front of one of the apartment buildings from 2012 features reproductions of the

\footnotetext{
${ }^{14}$ Hawes 2015.

${ }^{15}$ Bièvre-Perrin 2017.

16 Kiilerich 2014, 2020; Bièvre-Perrin 2019.

${ }^{17}$ Dior had staged a show on the Acropolis in 1951, but this was before mass-tourism and the quarrel over the return of the Parthenon sculpture.

${ }^{18}$ Examples can be found in https://antiquipop.hypotheses.org /; engramma.it; Vock 2002, 301-308; Kiilerich 2003, 2007.

${ }^{19}$ www.nunez-yanowsky.com/works/project/venus 18 residence (accessed 21 June 2021).
} 


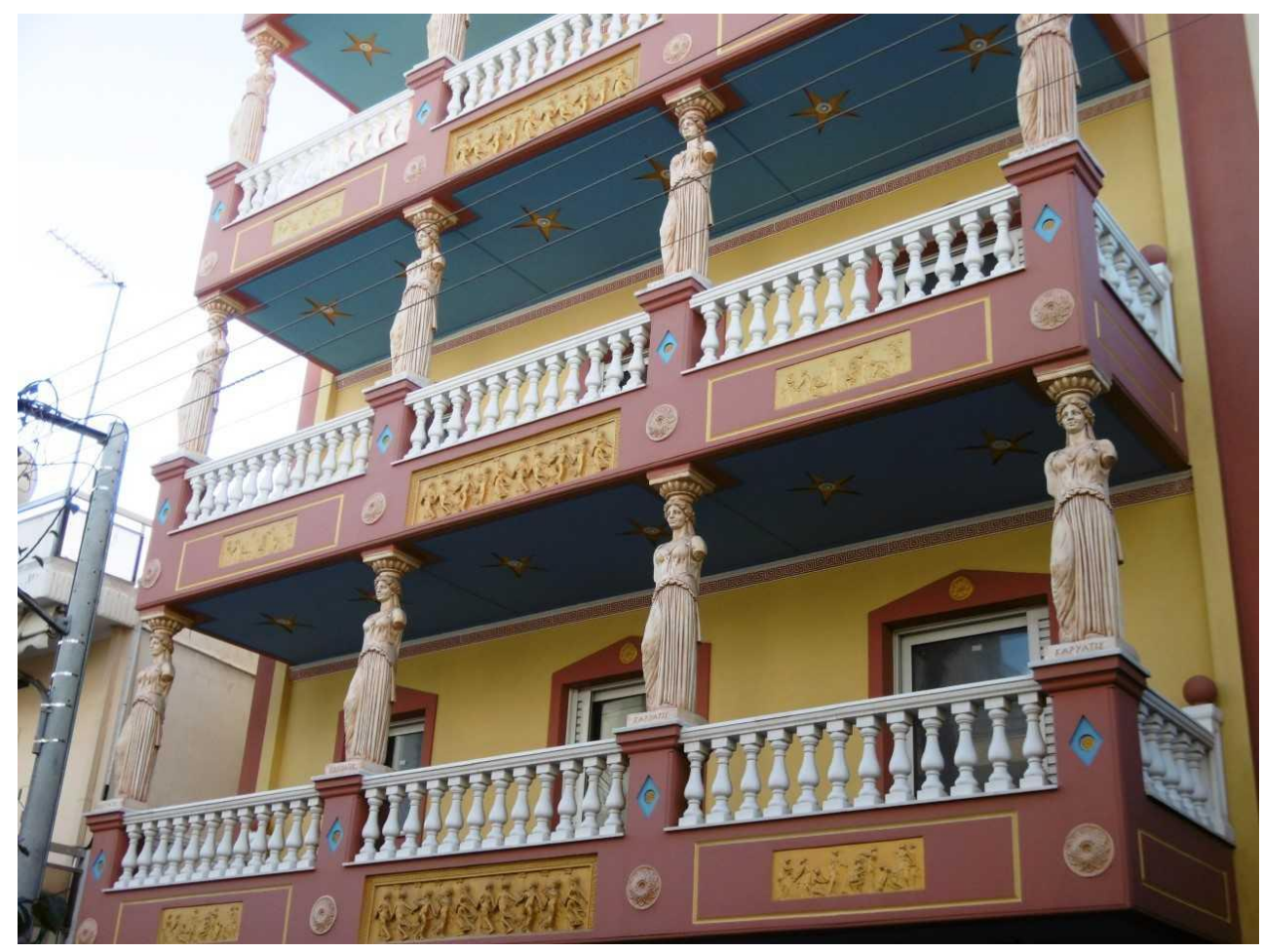

Fig. 2 Carytids in a modern building at Egaleo, Athens, 2012. (C) B. Kiilerich.

Erechtheion caryatids, a timely reappropriation of a classical image that over the centuries has been subject to a range of reuses and abuses (Fig. 2). ${ }^{20}$

The reader of this introduction may by now be exhausted by the listing of examples and by the name dropping. However, the enumeration which could have been even longer - serves to show that contemporary classicism, modern classicism, pseudo-classicism, neo-neo classicism, neo-neoantiquity, or whatever one prefers to call the multifarious phenomenon, actually is an all-encompassing global trend within art, design and visual culture. It therefore deserves our attention.

\section{Recycling sculpture - the prime example}

How can the current popularity of antique sculpture be understood? To cut a millennia-long story short: the classical idioms of the fifth and fourth centuries $\mathrm{BC}$ were transmuted in the Hellenistic period, when styles were liberally used, the classical now being influenced by several new styles, ranging from realistic

\footnotetext{
${ }^{20}$ Plantzos 2017 discusses the political implications of the caryatids, especially with regard to the one that was brought to London and has now become a potent symbol of the struggle over the Elgin/Parthenon marbles.
} 


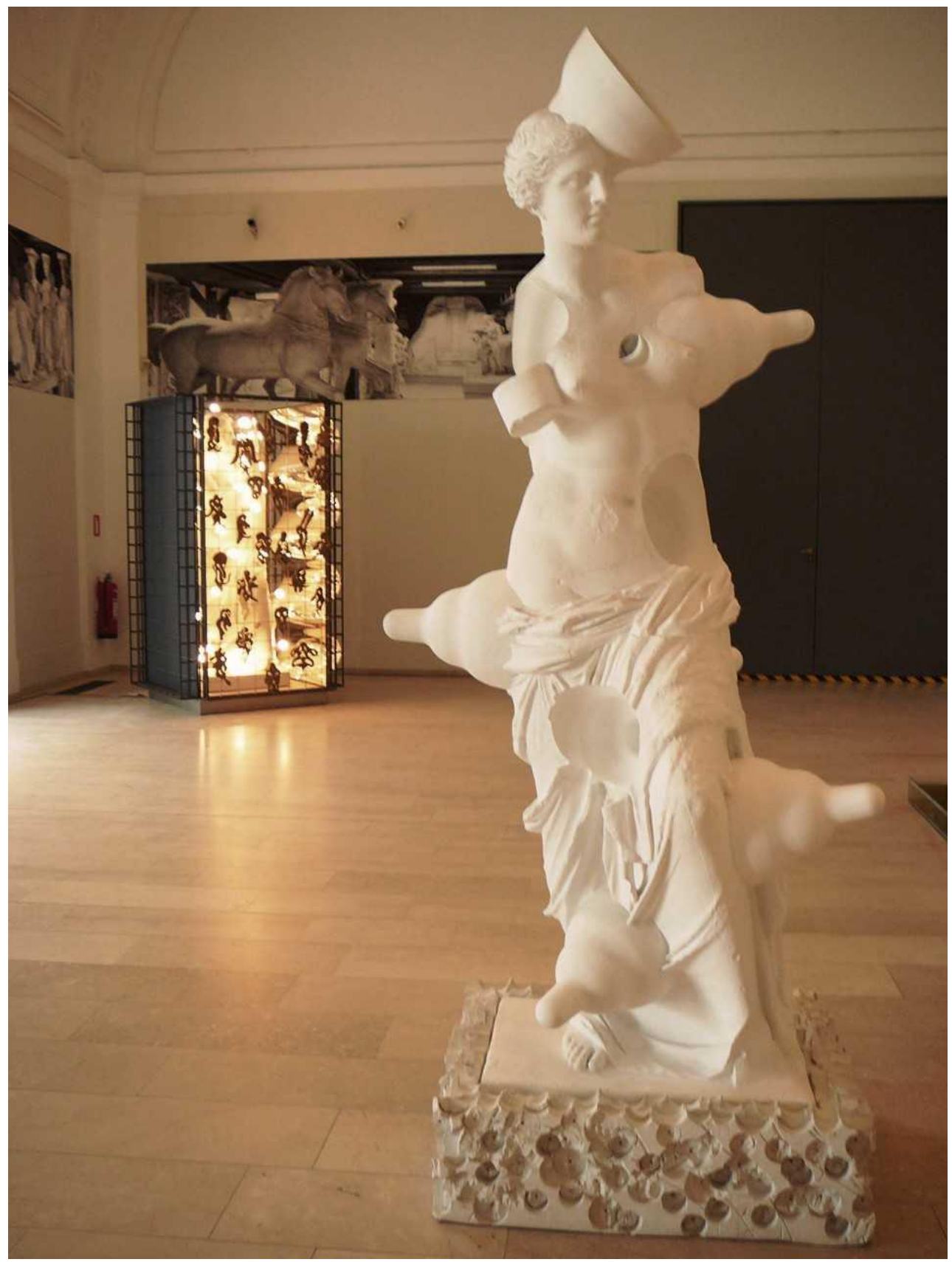

Fig. 3 Bjørn Nørgaard, Venus modification and Autoportrait, from the series Venus spejler - spejler Venus, 2005. Statens Museum for Kunst, Copenhagen.

(C) B. Kiilerich. 
to idealistic modes, often resulting in a stylistically mixed idiom. The Romans made copies, replicas and variations on classical and Hellenistic sculpture, an Aphrodite changing from cult statue to become, in some cases, a Venus serving as a garden ornament and art work, in still others to serve as a portrait statue fashioned with the portrait head of a Roman woman. ${ }^{21}$ Only a limited number of antique statues survived through the Middle Ages. In the Renaissance, these ancient works were regarded with interest and admiration whether they were judged Greek or Roman. New discoveries such as the Laocoon and the Belvedere torso gained special fame and came to influence the likes of Michelangelo. By the neo-classical period, the antique art works had become collectors' items, while newly made works such as Canova's Venus Italica joined company with the old ones. ${ }^{22}$

The Venus de Milo, which was only discovered in 1820, was hyped by the French and launched as a competitor to the famous Venus de' Medici; the armless sculpture was soon to become the most avidly cited and copied of all antiques, by far outdoing the Medici Venus. In the nineteenth century, the Venus de Milo was promulgated through small-scale plaster casts and the new medium of photography. ${ }^{23}$ A turning point in the history of its reception came in the twentieth century: Rene Magritte and Salvador Dali made subversive remakes of the Venus de Milo that were followed by those of other artists who presented the statue in various colours, with and without arms, beheaded, chained, battered, multiplied and manipulated in endless ways. ${ }^{24}$ Indeed, the Venuses of the twentieth- and twenty-first centuries are markedly different from those of the nineteenth century: while at first the sculpture was in focus, in modern and contemporary art, the sculptural form has become a vehicle for the artists' self-expression.

In 2005, Bjørn Nørgaard, court artist to the Danish Queen Margrethe II and former professor at the Royal Academy of Arts, used Venus de Milo as a model for his seven Venus mirrors - mirrors Venus installations (Fig. 3). ${ }^{25}$ Four years later, he presented a work entitled Recycling art (Venus fra Milo). It consisted of a plaster cast of the Venus de Milo placed in a green recycling bin carrying the label 'Recycling art'. ${ }^{26}$ Since then, the statue has been recycled by, among others, Alben, Daniel Arsham, Matthew Darbyshire, Omar Hassan, Yinka Shonibare, Fabio Viale, Xu Zhen and Cao Hui. The Venus de Milo has become a visual icon that transgresses chronological and geographical boundaries. It has become part of collective memory, a household brand, and a symbol that is useable for nearly all purposes. Indeed, the statue seems to

\footnotetext{
${ }^{21}$ See e.g. Perry 2005.

${ }^{22}$ For a thorough discussion of the life history of ancient artworks, see Vout 2018; Squire 2019.

23 See Cuzin et al. 2000, 432-438; Jockey 2011.

${ }^{24}$ For these and other artists, Arman, Jim Dine, Ruy-Blas, etc. etc., see Cuzin et al. 2000, 458-499; Salmon 2000; Prettejohn 2006, 2012.

${ }_{25}$ Kiilerich 2009, 244-249.

${ }^{26}$ Kiilerich 2012, 51, fig. 9.
} 
partake in Umberto Eco's 'endless semiosis', in which the visual qualities and meanings are endlessly commutable. Paradoxically, in antiquity the Venus de Milo was presumably a rather insignificant statue, one of many that decorated a theatre on the small island of Melos. Nobody could have foreseen her fame as a modern icon.

While the Venus de Milo remains by far the most popular, many other antique sculptures, such as the Nike of Samothrace, the Apollo Belvedere and the Laocoon have within recent years been subject to new interpretations and become vehicles for new discourses. The question must therefore be asked, why do artists from very different backgrounds, from Copenhagen to Milan, from New York to Shanghai, continue to (re)turn to antiquity for 'inspiration'? What sense, if any, does an antique statue make in the twenty-first century? And, what can we learn about archaeological artefacts when we see them through the eyes of contemporary artists? The articles in the present special issue focus on these questions as well as questions of current exhibition regimes and the use of antiquity in branding.

\section{The content of the present issue}

As the contributions to the present issue will show, although certain aspects are characteristic of the phenomenon across the spectrum, there are countless ways of engaging with antiquity and countless ways of reinterpreting and refashioning antique works, and there are many ways for archaeologists and art historians to interpret the results. As Jacques Rancière put it, although in a different context and primarily with French paintings in mind: 'The works of the past can be considered as forms for new contents and raw materials for new formations. They can be re-viewed, re-framed, re-read, re-made'. ${ }^{27}$ The continual popularity of Venus, Nike and Apollo, and the magnetism of the Colosseum are undoubtedly signs of the enduring artistic and technical quality of ancient artworks and architecture. More than two millennia after their original conception the monuments remain important not only for the study of classical archaeology but also for that of contemporary art and visual culture. We shall undoubtedly encounter many more new 'antique' statues for a long time to come and find new luxury brands engaging with possibilities of staging shows in ancient temples and arenas.

Prof. Bente Kiilerich

University of Bergen

Bente.kiilerich@uib.no

${ }^{27}$ Rancière 2002, 143. 


\section{References}

Besnard, T. A. 2018a: 'Compte rendu de l'exposition Londonienne "The Classical Now" (Mars-Avril 2018)', https://antiquipop.hypotheses.org/comptes-rendus/3500-2

Besnard, T. A. 2018b: 'L'empire des citations: vers un art contemporain "néonéoclassique"? In Antiquipop: La référence à l'antiquité dans la culture populaire contemporaine. Lyon: MOM Éditions https://books.openedition.org/momeditions/3335

Besnard, T. A. 2019a: 'Du Weathering Project aux autoportraits en Venus: les sculptures onctueuses et savonneuses de Meekyoung Shin, in Anabases no. 29, 71-86.

Besnard, T. A. 2019b: '(In)citations antiques. Les références à l'antiquité grecque et romaine dans l'art actuel', in Age of Classics. L'antiquité dans la culture pop, 178-207. Toulouse: Musée Saint-Raymond.

Besnard, T. A. 2019c: 'Un revival haut en couleur! (Re)presenter la polychromie antique dans la sculpture contemporaine', in Restituer les couleurs (Actes du colloque 29-30 novembre et 1 décembre 2017), 210-226. Bordeaux: Ausonius.

Bièvre-Perrin, F. 2017: 'La modernité de l'Antiquité -Chanel', Antiquipop 05/2017 https://antiquipop.hypotheses.org/2413 (accessed 15 February 2020.)

Bièvre-Perrin, F. 2019: 'L'Antiquité globalisé: Dolce et Gabbana dans la vallée des temples', Antiquipop 08/07/2019 https://antiquipop.hypotheses.org/7012 (accessed 15 February 2020)

Bloom, L. E. 2009: ‘Tableaux Vivants, Dying Empires: Eleanor Antin’s The Last Days of Pompeii', n.paradoxa 24: 13-21.

Costantini, C. 2004: L'enigma della pietra. Conversażoni con Igor Mitoraj. Rome: il Cigno.

Cuzin, J.-P., R. Gaborit \& A. Pasquier (eds) 2000: D'après l'antique. Paris: Louvre.

Di Stefano, E. (ed.) 1998: L'ombra degli dei. Mito greco e arte contemporanea. Naples: Electa. 
Filser, W. 2018: 'Eleanor Antin's Historical Takes. Paradigm of a Postmodern View on Classical Antiquity?', Pegasus. Berliner Beiträge zum Nachleben der Antike, 18/19: 279-305.

Georgiadou-Kountoura, E. 2008: Alexandros Isaris. O neos tis Motyis kai alla mystiria. Zografiki 2004-2007. Athens: Indiktos.

Hawes, G. 2015: 'The Unsettled Settler: Herakles the Colonist and the Labours of Marion Maguire', Arion. A Journal of Humanities and the Classics 23.2: 11-27.

Holmes, B. \& K. Marta (eds) 2017: Liquid Antiquity, Geneva \& Athens: Deste.

Howorus-Czajka, M. 2018: 'Broken Heroes ... Kitsch or Art? Reception of Igor Mitoraj's Works', Roczniki Humanistyczne 66: 4: 151-172.

http://dx.doi.org/10.18290/rh.2018.66.4-8 (accessed 15 June 2021).

Jensen, I. \& A. Wieczorek (eds) 2002: Dino, Zeus und Asterix. Zeitrenge

Archäologie in Werbung, Kunst und Alltag heute. Mannheim: Beier \& Beran.

Jockey, Ph. 2011: 'The Venus de Milo: Genesis of a Modern Myth', in Z.

Bahrani, Z. Celik \& E. Eldem (eds), Scramble for the Past. A Story of Archaeology in the Ottoman Empire, 219-238. Istanbul: SALT.

Kaiser, L. 2003: L'anacronismo e il ritorno alla pittura. L'origine è la meta. Milan: Silvana Editoriale.

Kiilerich, B. 2003: 'Duften af Antinoos. Nutid og fortid - møde eller konfrontation', Klassisk Forum 2003: 2, 83-87.

Kiilerich, B. 2005: 'Mitorajs moderne myter - nyt liv til gamle former', Klassisk Forum 2005: 2, 46-57.

Kiilerich, B. 2006: 'From Greek Original to Modern Pastiche: the Reformulation of the Classical Statue in Contemporary Art', ActaAArtHist XX, n.s. 6: 241-265.

Kiilerich, B. 2007: 'Det klassiske og reklamen', Klassisk Forum 2007:1, 37-44.

Kiilerich, B. 2009: 'Gamle statuer i nye værker', in M. Skoie \& G. Vestrheim (eds), Antikken i ettertiden, 240-250. Oslo: Universitetsforlaget.

Kiilerich, B. 2012: 'Venus de Milo - brug, misbrug og genbrug', Klassisk Forum 2012:2, 42-52. 
Kiilerich, B. 2014: 'Arkæologisk sommermode 2014', Klassisk Forum 2014:1, 32-42.

Kiilerich, B. 2018: 'Nike - fra Samothrake til Shanghai', Klassisk Forum 2018:2, 70-83.

Kiilerich, B. 2019: 'The Classical in Contemporary Sculpture: A Global View', PoDIA IX: 103-113.

Kiilerich, B. 2020: 'Mytologi på mode: Dolce \& Gabbanas 'græske' kollektioner', Klassisk Forum 2020: 1, 37-49.

Kiilerich, B. 2021: 'Sovende figurer - fra antik "haveskulptur" til samtidskunst', Klassisk Forum 2020: 2 (2021): 36-54.

Lambraki Plaka, M. (ed.) 2000: Classical Memories in Modern Greek. Art. New York: Onassis Cultural Center.

Lambraki Plaka, M. (ed.) 2007: Classical Memories in Modern Greek Art. Peking: Capital Museum of China; Athens: National Gallery \& Alexandros Soutzos Museum: Hellenic Ministry of Culture.

Lane, C. (ed.) 2011: Carlo Maria Mariani in the Twenty-First Century. Milan: Skira.

Masiero, R. (ed.) 1990: Neoclassico. L'attualità: arte, architettura, design. Venezia: Marsilio Editori.

Mavrotas, T. (ed.) 2008: Psychopedis, Nostos. Athens: Museum of Cycladic Art.

Mitoraj, I. 2004: Mitoraj ai Mercati di Traiano. Rome: ArtMedia.

Perry, E. 2005: The Aesthetics of Emulation in the Visual Arts of Ancient Rome. Cambridge: Cambridge University Press.

Plantzos, D. 2017: 'Caryatids lost and regained: rebranding the Classical Body in Contemporary Greece', Journal of Greek. Media \& Culture 3(1): 3-29.

Prettejohn, E. 2006: 'Reception and Ancient Art: the Case of the Venus de Milo', in C. Martindale \& R.F. Thomas (eds), Classics and the Uses of Reception, 227-249. Malden: Blackwell.

Prettejohn, E. 2012: The Modernity of Ancient Sculpture. Greek Sculpture and Modern Art from Winckelmann to Picasso. London-New York. 
Rancière, J. 2002: 'The Aesthetic Revolution and its Outcomes', New Left Review 14, 133-151 (reprinted in J. Rancière, Dissensus - On Politics and Aesthetics, 2010, 115-133. London: Continuum).

Salmon, D. 2000: La Vénus de Milo - un mythe. Paris: Musée du Louvre.

Sanguinetti, C et al. 1995: Il mito e il classico nell'arte contemporanea italiana 19601990. Milan: Mazzotta.

Shields, S.A., D. Rodes \& P. Junker, 2015: David Ligare. California Classicist. Winterbourne: Papadakis.

Soavi, G. 2003: Il sapore di quelle bocche. Sculture di Mitoraj. Milan: Skira.

Squire, M. et al. 2018: The Classical Now. London: Elephant Books.

Squire, M. 2019: 'Reception: the Legacy of Greek Sculpture', in: O. Palagia (ed.), Handbook of Greek Sculpture, 725-767. Berlin: De Gruyter.

Trione, V. (ed.) 2013: Post-classici. La ripresa dell'antico nell'arte contemporanea italiana. Milan: Electa.

Vock, M. 2002: 'Werbung mit Antiken in der Bekleidungsbranche'; 'Antiken in der Pharmawerbung', in I. Jensen, \& A. Wieczorek (eds), Dino, Zeus und Asterix. Zeitzenge Archäologie in Werbung, Kunst und Alltag heute, 301-308. Mannheim: Beier \& Beran.

Vout, C. 2018: Classical Art. A Life History from Antiquity to the Present. Princeton: Princeton University Press.

Zummer, Th. 2006: 'Seeing Double. Eleanor Antin's Roman Allegories', PAJ: a Journal of Performance and Art 28 (2): 80-88.

Zuschlag, C. 2010: 'Transformationen der Antike in der zeitgenössischen Kunst', in T. Bartsch, M. Becker, H. Bredekamp \& C. Schreiter (eds), Das Originale der Kopie: Kopien als Produkte und Medien der Transformation von Antike, 310-328. Berlin: De Gruyter (Transformationen der Antike 17). 